\title{
Cartesian Skepticism ANd Internal ReAlism
}

\author{
Nicholas TebBen
}

\begin{abstract}
The Cartesian skeptic's strategy is to tell a story about the world that is entirely consistent with all of the empirical evidence that we do, or can, have, but according to which many or all of our ordinary beliefs are false. He then suggests that, since we cannot show that his story is false, we ought to surrender those beliefs. In this paper I offer a decisiontheoretic response to skepticism. Say that a cognitive attitude is a propositional attitude that may be true or false. I argue that rejecting the skeptic's story, and so retaining our ordinary opinions, will yield for us true cognitive attitudes, no matter whether the skeptic's story is true or false, and that the best any alternative can do is yield no cognitive attitudes at all. Hence, it is rational to retain our ordinary opinions. One may be concerned that I can maintain this surprising conclusion because the cognitive attitudes at issue are not real beliefs, and do not represent the real world. I conclude the paper by arguing that this concern is misplaced.
\end{abstract}

Keywords: Skepticism; reference; dreams; decision theory.

\section{Introduction}

The Cartesian skeptic argues, first, by offering a skeptical hypothesis - a description of a world that is evidentially indistinguishable from, but largely or entirely different than, the real world - and then claiming that, since the skeptical hypothesis cannot be shown not to obtain, we are not justified in holding those of our ordinary opinions that are incompatible with it. Since it is a familiar fact that our empirical theories are underdetermined by the evidence that we have for them, it is tempting to see Cartesian skepticism as a generalization of this point. Just as scientific theories go a step beyond what the evidence for them entails (and so that evidence does not rule out every competing hypothesis), so any belief about the external world goes a step beyond what the evidence for it entails. The evidence that we have for our ordinary views does not rule out the possibility that we are dreaming, for example, or the possibility that we are victims of massive deception. Some have argued, however, that, because of its global nature, there are important disanalogies between the skeptic's challenge and the local underdetermination problems that are encountered in scientific contexts.

In the early pages of Reason, Truth and History, Putnam argues that in order for an expression (or thought) ' $x$ ' to refer to $Y$, there must be an appropriate causal connection between the token of ' $x$ ' and the object Y. He takes this fact to show that our thoughts and utterances refer to objects in our actual environment, whatever those

Principia 17(2): 251-264 (2013).

Published by NEL — Epistemology and Logic Research Group, Federal University of Santa Catarina (UFSC), Brazil. 
happen to be. This has interesting consequences for certain skeptical hypotheses. Putnam asks his readers to consider, for example, the skeptical hypothesis that they are, and have been for their whole lives, disembodied brains, kept alive in a vat of nutrients by mad scientists and fed neural inputs that provide them with all of the experiences that they actually have. This is a hypothesis that is consistent with all of the empirical evidence that his readers might have, but it is, he says, necessarily false. The problem, Putnam claims, is that: "although [those in such a situation] can think and 'say' any words we can think and say, they cannot ... refer to what we can refer to. In particular they cannot think or say that they are brains in a vat (even by thinking 'we are brains in a vat')." (Putnam 1981, p.8. The italics are in the original.) They are not able to think, or say, that they are brains in a vat, because their use of 'brain', or 'vat', refers to the only the "brains" or the "vats" with which they have had appropriate causal contact, namely, the images of brains and the images of vats delivered to them by the vat in which they are imprisoned.

Putnam has said, in conversation, that he did not intend this as an anti-skeptical argument, and it does not work as one. Say that one has only recently become a victim of massive deception: then one will have established the required causal connections to real things, and one's beliefs will mostly be false. I will argue, however, that it does have some anti-skeptical significance. In fact, I will argue that Putnam's causal condition on reference, when combined with a view of the nature of dreams (and, by extension, similar states) pioneered by Norman Malcolm (see Malcolm 1959) and recently revived by Ernest Sosa (see Sosa 2007), does allow us to offer a response to Cartesian skepticism.

The next section develops, and argues for, Malcolm and Sosa's account of the cognitive lives of dreamers. Section three uses that view to respond to one limited kind of skepticism - Descartes' dream skepticism of the first meditation. Section four discusses Putnam's causal condition on reference, and uses the causal condition to extend the response to dream skepticism out to any kind of Cartesian skepticism.

Now, the views under discussion here allow a response to skepticism in that they permit us to see that the skeptic's doubts are misplaced, and so to guarantee that cognitive agents have nothing to fear by ignoring them. The response does not, however, proceed by examining the evidence and concluding that it is unlikely that any of the skeptic's hypotheses are true. ${ }^{1}$ Rather, I argue that, whatever the world is like, we do better, qua epistemic agents, to retain our ordinary beliefs and dismiss skeptical hypothesis. I suspect that some will find this unsatisfying. In particular, I anticipate that some will be concerned that I have traded one kind of skepticism for another. ${ }^{2}$ At the end of the paper I argue that this concern is unfounded. 


\section{Dreams}

Dream skepticism, of the kind that Descartes considers at the beginning of the first meditation, works under the assumption that the cognitive lives of dreamers do not differ, in any epistemically relevant sense, from those who are up and about. In particular, the dream skeptic supposes that the representations that dreamers form are genuine beliefs, like those that I am able to form right now, and that they at least purport to represent the waking world. Call the hypothesis that there is no relevant difference between the cognitive lives of dreamers and those who are awake, 'H1'.

It is not obvious that $\mathrm{H} 1$ is correct. Malcolm and Sosa have both argued against it. Malcolm's objection to $\mathrm{H} 1$ is that the criteria for attributing propositional attitudes to people are incompatible with those for saying that someone is dreaming. (See Malcolm 1959, p.36-51.) Sosa also argues against H1. He has two grounds for complaint. The first is that it violates the principle of charity. ${ }^{3}$ Sosa says that we do not need to re-acquire all of our beliefs each morning, but that, rather, they are preserved from the previous day. So even those who are asleep and dreaming still believe that they are lying in bed. (See Sosa 2007, p.4-5.)

Now, say that Rachel dreams that she is being chased by a lion. If, upon waking, she does not need to re-acquire the belief that she is lying in bed, then to attribute to her the belief that she is being chased by a lion would entail attributing to her beliefs that could not both be true: that she is in bed, and that she is being chased by a lion. The principle of charity requires that we minimize the incoherence that we attribute to subjects of interpretation. So, since the supposition that Rachel believes that she is in bed is unproblematic, the principle of charity requires that whatever other cognitive attitudes we attribute to her must not be beliefs that are inconsistent with this one. And so we must not attribute to her the belief that she is being chased by a lion.

Sosa's second objection to $\mathrm{H} 1$ is that mental states one enters into while dreaming are not, in general, of the same kind as those states that one enters into while awake. If Simon dreams that he has the intention to kill his brother, he is not thereby a danger to his brother. And the reason that he is not a danger to him is not that he changes his mind when he wakes up. The reason is that dreamt intentions are not real intentions. As it is with intentions, so it is with beliefs. If Olga dreams that she believes that she can fly, when she wakes up she is not likely to leap from the top a building. And the reason that she is not likely to do so is not that, when she wakes up, she changes her mind about whether or not she can fly. The reason is that her dreamt belief was not a real belief. (Sosa 2007, p.5-7.)

I would like to offer one more objection to $\mathrm{H} 1$. $\mathrm{H} 1$ is objectionable because it would force us to deny something that is obvious: namely, that dreamers often can represent their dreams to themselves. If Olga dreams that she believes that she can 
fly, and upon leaping off of a building (in her dream), she finds that she can fly, we should be able to say that her earlier representation was true. We should be able to say that she accurately represented her dream to herself (although, of course, she did not know that it was a dream), and $\mathrm{H} 1$ would force us to deny this.

Recognizing that dreamers can represent their dreams to themselves may tempt one to adopt:

H2: If one dreams that one believes that $p$, one thereby believes that $p$-in-adream.

The belief that $p$-in-a-dream is merely the belief that $p$ occurred in one's dream. $\mathrm{H} 2$ has some virtues that $\mathrm{H} 1$ lacks. For example, attributing to a dreamer both the belief that s/he is lying in bed, and the belief that s/he is being chased-by-a-lion-ina-dream is consistent with the principle of charity. Both can be true. It is also not clear that Sosa's second objection has application here. Olga, who dreamt that she believes that she can fly, is not likely to leap off of a building upon waking up. But if her dreamt belief was really a belief that she can fly-in-a-dream, then we have an easy explanation of why she won't leap off of a building: in the waking world, one does not act on beliefs about one's dreams.

Nevertheless, $\mathrm{H} 2$ is unattractive. Its main failing is that it divorces the cognitive lives of dreamers from the evidence that they have available. If Rachel dreams that she is being chased by a lion, her evidence is not evidence for the proposition that she is being chased by a lion-in-a-dream; rather, her evidence is evidence for the proposition that she is being chased by a lion. Given a better option, H2 ought to be rejected.

So consider:

H3: If one dreams that one believes that $p$, one merely believes-in-a-dream that $p$.

A belief-in-a-dream is not a belief. It is a distinct propositional attitude, and one that represents the dream of which it is a part. So if Olga believes-in-a-dream that she can fly, and if, in her dream, she leaps off of a building and takes flight, her belief-in-adream will have turned out to be true. Similar remarks apply to other propositional attitudes. To dream that one intends to make it the case that $p$ is not to intend to make it the-case-in-a-dream-that- $p$. It is, rather, to intend-in-a-dream to make it the case that $p$. This is the hypothesis that Sosa opts for. ${ }^{4}$

$\mathrm{H} 3$ is not subject to the same objections as $\mathrm{H} 1$ and $\mathrm{H} 2$. Adopting $\mathrm{H} 3$ allows us to respect the principle of charity. One can, coherently, both believe that one is asleep in bed, and believe-in-a-dream that one is being chased by a lion. Since beliefs-in-adream are not beliefs, $\mathrm{H} 3$ also allows us to explain why Olga, upon awaking from her dream in which she dreamed that she believed that she could fly, is unlikely to leap

Principia 17(2): 251-264 (2013). 
off of a building. In the waking world, we act on beliefs, not beliefs-in-a-dream. It also does not divorce dreamers' cognitive lives from their evidence. If Rachel dreams that she believes that she is being chased by a lion, she will form the belief-in-adream that she is being chased by a lion. Since the proposition to which she takes an attitude is that she is being chased by a lion, and since the proposition that her evidence supports is the very same one, her cognitive life remains grounded in the evidence that she has available. Given its advantages over the alternatives, H3 will be assumed in what follows, with one notable exception.

The exception covers those cases in which one has good evidence that one is dreaming. For example, if one's experience displays sudden incoherence or lack of continuity, that fact may be a good indication that one is dreaming. That no waking state can be distinguished from some dreaming states does not establish that no dreaming state can be distinguished from some waking state. When someone does have good evidence that they are dreaming, it may make good sense to attribute to them the belief that $p$-in-a-dream rather than the belief-in-a-dream that $p$, since they have come to occupy an epistemic perspective from which they can tell that, say, they are not being chased by a lion, but only dream that they are. Indeed, in some situations it may even make good sense to attribute to them beliefs about the waking world. Dreamers who recognize their dreams for what they are can form the belief that $p$, as well as the belief that $p$-in-a-dream. All other dreamers can only believe-in-a-dream that $p$.

Since having good evidence that one is dreaming requires that one's experience lacks continuity or takes an incoherent turn, say that anyone who has good evidence that they are dreaming occupies an incoherent epistemic perspective. All other epistemic perspectives - those occupied by individuals in the waking world and those occupied by dreamers with coherent dreams - call coherent epistemic perspectives.

\section{Dream Skepticism}

Sosa's theory of dreams provides him with the basis for a response to dream skepticism. Consider the question of whether or not to believe that you are presently awake. You have, Sosa says, three options: believe that you are awake, believe that you are asleep and dreaming, and suspend judgment on the question. But if you can so much as consider which option to choose, as opposed to consider-in-a-dream, then you are awake. And so it is only advisable to believe that you are awake. Here is Sosa's summary of his argument:

Should one think that for all we know our current conscious life is nothing but a dream? Given our conception of dreams, how could one even sensibly entertain that possibility? If one is dreaming, then one cannot be pondering

Principia 17(2): 251-264 (2013). 
any such question as whether one might be only dreaming, and one cannot possibly assent to any answer, whether affirmative or negative. Knowing this, how can one sensibly deliberate on whether one might be dreaming? On our conception of dreams, one is automatically, rationally committed to supposing that one is not just dreaming, whenever one inquires at all. It is hard to imagine a better answer to the dream skeptic. (Sosa 2007, p.20. The italics are in the original.)

Though the Malcolm/Sosa theory of dreams is very attractive, the anti-skeptical use to which Sosa puts it is unsatisfying. The dream skeptic's response to this line of argument is obvious: show me that you really are inquiring, and not just dreaming that you are inquiring. If it has, as Sosa claims, been shown that ordinary mental activities, including believing, deliberating, and inquiring, presuppose that the believer, deliberator or inquirer is not dreaming, it would be illegitimate to appeal to the fact that one is believing that $p$, deliberating about whether or not $p$, or inquiring whether or not $p$, when responding to a dream skeptic.

Nevertheless, Sosa's view can be employed in a successful response to dream skepticism. Allow me to introduce the term 'n-belief', which is neutral between referring to beliefs and beliefs-in-a-dream. Allow similar terms for other propositional attitudes, and allow verbs like 'n-believes' ${ }^{5}$ One interesting property of n-beliefs is that they are truth-apt propositional attitudes. They are, in this respect, like beliefs, but unlike fear. Call such attitudes 'cognitive attitudes'.

Just as cognitive agents can ask about what they should believe, so they can ask about what they should n-believe. Indeed, this may be the more fundamental question, as believing and believing-in-a-dream are, from any coherent epistemic perspective, indistinguishable. The dream skeptic urges cognitive agents to suspend n-judgment on whether they are awake or dreaming. Is this good advice? There is reason to think that it is not.

Consider the following, and assume throughout that you occupy a coherent epistemic perspective. First, if you are awake, then n-believing that you are awake produces in you the true belief that you are awake. Now, consider the possibility that you are merely dreaming that you are awake. If you are, then n-believing that you are awake yields the true belief-in-a-dream that you are awake, as, in your dream, you are awake. By contrast, if you n-believe that you are dreaming while you are awake, you get the false belief that you are dreaming, and if you n-believe that you are dreaming while you are dreaming, you get the false belief-in-a-dream that you are dreaming. Moreover, following the skeptic's advice yields no cognitive output, true or false. See Figure 1. 


\begin{tabular}{|l|l|l|l|}
\hline & $\begin{array}{l}\text { N-believe that you } \\
\text { are awake }\end{array}$ & $\begin{array}{l}\text { N-believe that you } \\
\text { are dreaming }\end{array}$ & $\begin{array}{l}\text { Suspend } \\
\text { n-judgment }\end{array}$ \\
\hline You are awake & $\begin{array}{l}\text { You get the true } \\
\text { belief that you are } \\
\text { awake }\end{array}$ & $\begin{array}{l}\text { You get the false } \\
\text { belief that you are } \\
\text { dreaming }\end{array}$ & No payoff \\
\hline You are dreaming & $\begin{array}{l}\text { You get the true } \\
\text { belief-in-a-dream } \\
\text { that you are awake }\end{array}$ & $\begin{array}{l}\text { You get the false } \\
\text { belief-in-a-dream } \\
\text { that you are } \\
\text { dreaming }\end{array}$ & No payoff \\
\hline
\end{tabular}

Figure 1.

The dream skeptic's advice is not good. No matter whether you are awake or dreaming, you do better, cognitively speaking, to n-believe that you are awake, than you would by n-believing that you are dreaming, or by suspending n-judgment. In fact, no matter whether you are awake or dreaming, n-believing that you are awake gives you a true cognitive attitude. This, I take it, is enough to respond to dream skepticism. If our cognitive goal is to create a comprehensive and accurate picture of the world, then suspending n-judgment is not epistemically rational, but n-believing that we are awake is. The skeptic recommends suspension of belief (or of n-belief, as the case may be), in order to avoid including an inaccurate belief in one's picture of the world. But n-believing that one is awake poses no danger of introducing an inaccurate belief, or any other cognitive attitude, into one's picture of the world. One's picture of the world is improved, no matter what the world is like.

\section{Radical Skepticism}

Dream skepticism is only one kind of Cartesian skepticism, and not the most threatening. Dream skepticism retains some empirical theory - that there is an external world, which is, in its general outlines, more-or-less like we believe it to be, in which we often sleep - and points out that the rest of our theory - that the world has the particular character we take it to have - is underdetermined by the evidence that we have available. But the most severe version of Cartesian skepticism gets its grip by pointing out that even the theoretical commitments on which dream skepticism relies are underdetermined by our evidence.

Radical Cartesian skepticism, accordingly, relies on outlandish skeptical hypotheses: that one is a victim of an all-powerful demon bent on deception, or that one is really a disembodied brain kept alive in a vat of nutrients and fed electrical impulses that produce sensations as of the ordinary external world. Since no evidence tells against these hypotheses, the skeptical argument says, our ordinary beliefs about the external world are unjustified.

Principia 17(2): 251-264 (2013). 
I will argue that essentially the same strategy that allowed us to dispatch dream skepticism will also work for radical skepticism. Just as dreamers can represent their dreams to themselves, so victims of massive deception can represent to themselves the illusions with which they are deceived. On analogy with ' $n$-belief', let ' $n$ *-belief' be neutral between referring to beliefs and beliefs-in-the-illusion.

The argument against radical skepticism is somewhat more involved than that against dream skepticism, because being deceived ${ }^{6}$ is not perfectly analogous to dreaming. Recall that the one important rationale for attributing to dreamers beliefsin-a-dream, rather than ordinary beliefs, is that it is demanded by the principle of charity. Were someone to become a victim of Descartes' demon, or a mad scientist, or what-have-you, the same reasoning that showed that dreamers should be attributed only beliefs-in-a-dream instead of real beliefs would show that the victim of deception should be attributed only beliefs-in-an-illusion instead of real beliefs. Those who come to be deceived already have a stock of beliefs, and further attributions of cognitive attitudes should be consistent with those beliefs. Hence they must be attributed only new beliefs-in-an-illusion, for attributing to them new beliefs would require attributing to them an incoherent belief set.

But one important respect in which sleeping is not analogous to being deceived is that one might have been deceived from the beginning. Charity does not require attributing mere beliefs-in-an-illusion to those who have been deceived from the beginning, because they have no established stock of beliefs with which new beliefs might conflict.

So the decision matrix for radical skepticism is $3 \times 3$ instead of $3 \times 2$, and the last row is yet to be filled in. See Figure 2.

\begin{tabular}{|l|l|l|l|}
\hline & $\begin{array}{l}\mathbf{N}^{*} \text {-believe that you } \\
\text { are not a victim of } \\
\text { deception. }\end{array}$ & $\begin{array}{l}\mathbf{N}^{*} \text {-believe that you } \\
\text { are a victim of } \\
\text { deception. }\end{array}$ & $\begin{array}{l}\text { Suspend } \\
\mathbf{n}^{*} \text {-belief }\end{array}$ \\
\hline $\begin{array}{l}\text { You are not a } \\
\text { victim of deception. }\end{array}$ & $\begin{array}{l}\text { You get the true } \\
\text { belief that you are not } \\
\text { a victim of deception. }\end{array}$ & $\begin{array}{l}\text { You get the false } \\
\text { belief that you are a } \\
\text { victim of deception. }\end{array}$ & No payoff \\
\hline $\begin{array}{l}\text { You have only } \\
\text { recently become a } \\
\text { victim of deception }\end{array}$ & $\begin{array}{l}\text { You get the true } \\
\text { belief-in-an-illusion } \\
\text { that you are not a } \\
\text { victim of deception. }\end{array}$ & $\begin{array}{l}\text { You get the false } \\
\text { belief-in-an-illusion } \\
\text { that you are a } \\
\text { victim of deception. }\end{array}$ & No payoff \\
\hline $\begin{array}{l}\text { You have always } \\
\text { been a victim } \\
\text { of deception. }\end{array}$ & ???? & ???? & No payoff \\
\hline
\end{tabular}

Figure 2.

To complete the table, I propose to borrow an argument from Hilary Putnam. Putnam argues that successfully referring to something requires either that one have 
causal commerce with it oneself, or that one's use of an expression (or thought token) that refers to it must be the product of a causal chain of an appropriate kind, which can be traced back to that thing. So, to use Putnam's example, if an ant walks across a field of sand and traces a line that looks like a caricature of Winston Churchill, it is, nevertheless, not a picture of Churchill. The reason it is not is that the ant never had the occasion to interact with the man, and Churchill does not, himself, appear at any point in the causal chain that led to the production of this line in the sand. (See Putnam 1981, chapter 1.) By contrast, when I draw a picture of Churchill, it is a picture of Churchill because the causal chain that led to its production includes, for example, a film of Churchill, which, of course, has Churchill himself as part of its causal history. The referential properties of words or thoughts do not work differently. Had the ant traced the words 'Winston Churchill', it would not have referred to Churchill because the production of those "words" was causally isolated from the Prime Minister, whereas my production of 'Winston Churchill' manages to refer to him, because it is not.

Now, the fact that talking about something requires causally interacting with it (in the right way), or that it lies at the end of a causal chain (of the right kind) that led to one's verbal act, has some significant consequences for epistemology. In particular, it shows that certain kinds of skeptical hypotheses can be dismissed out of hand. Here is Putnam on the topic:

Suppose the whole story [that we are merely brains in vats] were actually true. Could we, if we were brains in a vat in this way, say or think that we are?

I am going to argue that the answer is 'No, we couldn't.' In fact, I am going to argue that the supposition that we are actually brains in a vat, although it violates no physical law, and is perfectly consistent with everything we have experienced, cannot possibly be true. It cannot possibly be true, because it is, in a certain way, self-refuting. (Putnam 1981, p.7. The italics are in the original.)

The problem with the hypothesis that we are actually brains in a vat, Putnam thinks, is that brains in a vat do not have (the right kind of) causal commerce with the vat in which they are imprisoned in order to be able to refer to it. In short, what Putnam is saying, is that when a brain in a vat says, or thinks, 'I am a brain in a vat', what it is saying or thinking is really I am a brain in a vat-in-an-illusion. (It does not, however, know that that is what it is saying or thinking.) And that claim, of course, is false. In the illusion, the speaker or thinker is not imprisoned in a vat.

This is not quite right, however. And when Putnam is being careful he notices that it is not. A little later he says:

when the brain in a vat (in a world where every sentient being is and always was a brain in a vat) thinks 'There's a tree in front of me', his thought does

Principia 17(2): 251-264 (2013). 
not refer to actual trees.... [Given the picture of reference offered here] the brain is right, not wrong in thinking 'There's a tree in front of me.' Given what 'tree' refers to in vat-English and what 'in front of' refers to, ... the truth conditions for 'There's a tree in front of me' when it occurs in vatEnglish are simply that a tree in the image be 'in front' of the 'me' in question — in the image ... And these truth conditions are certainly fulfilled. (Putnam 1981, p.14. I have suppressed Putnam's italics and added my own.)

The qualification "and always was" is important here. Those who have always been imprisoned in vats cannot refer to those vats. But the rest of us have established the causal connections that are required to successfully refer to real vats, and hence if we believe: 'we are brains in vats' our belief is simply that we are brains in vats, even if we have been kidnapped and put into the vat. So Putnam's reference externalism will not, as it stands, do as a response to radical skepticism.

What Putnam's theory does do, however, is allow us to fill in the last row in our decision matrix. When one who has always been a victim of deception (of the kind envisioned by Descartes) thinks 'I am a victim of deception', the content of that thought is I am a victim of deception-in-an-illusion, since s/he cannot refer to the deception (imprisonment in a vat, or whatever) of which $s /$ he is a subject. See Figure 3.

\begin{tabular}{|l|l|l|l|}
\hline & $\begin{array}{l}\mathbf{N}^{*} \text {-believe that you } \\
\text { are not a victim of } \\
\text { deception. }\end{array}$ & $\begin{array}{l}\mathbf{N}^{*} \text {-believe that you } \\
\text { are a victim of } \\
\text { deception. }\end{array}$ & $\begin{array}{l}\text { Suspend } \\
\mathbf{n}^{*} \text {-belief }\end{array}$ \\
\hline $\begin{array}{l}\text { You are not a } \\
\text { victim of deception. }\end{array}$ & $\begin{array}{l}\text { You get the true } \\
\text { belief that you are } \\
\text { not a victim of } \\
\text { deception. }\end{array}$ & $\begin{array}{l}\text { You get the false } \\
\text { belief that you are a } \\
\text { victim of deception. }\end{array}$ & No payoff \\
\hline $\begin{array}{l}\text { You have only } \\
\text { recently become a } \\
\text { victim of deception }\end{array}$ & $\begin{array}{l}\text { You get the true } \\
\text { belief-in-an-illusion } \\
\text { that you are not a } \\
\text { victim of deception. }\end{array}$ & $\begin{array}{l}\text { You get the false } \\
\text { belief-in-an-illusion } \\
\text { that you are a victim } \\
\text { of deception. }\end{array}$ & No payoff \\
\hline $\begin{array}{l}\text { You have always } \\
\text { been a victim } \\
\text { of deception. }\end{array}$ & $\begin{array}{l}\text { You get the true } \\
\text { belief that you are } \\
\text { not a victim of } \\
\text { deception-in-an- } \\
\text { illusion }\end{array}$ & $\begin{array}{l}\text { You get the false } \\
\text { belief that you are a } \\
\text { victim of deception- } \\
\text { in-an-illusion. }\end{array}$ & No payoff \\
\hline
\end{tabular}

Figure 3.

As in the case of dream skepticism, should you be only recently deceived, charity requires that we attribute to you not beliefs, but beliefs-in-an-illusion. And in that case, your belief-in-an-illusion that you are not being deceived is true. The response 
to radical skepticism is more involved than the response to dream skepticism, because should you have always been a victim of deception, charity does not require that we attribute to you beliefs-in-an-illusion. But Putnam's reference externalism takes care of this case. One who has always been a victim of deception has not established the causal connections necessary to talk or think about things in the real world. So if one in such an unfortunate situation believes 'I am a victim of deception', their belief must be false, because it refers only to deceptions within the illusion, not the deception of which the thinker is a subject. So, no matter whether or not one is a victim of deception, of the kind envisioned by the radical skeptic, $\mathrm{n}^{*}$-believing that one is not so deceived produces a true cognitive attitude, and $\mathrm{n}^{*}$-believing that one is so deceived produces a false one. Moreover, suspending $\mathrm{n}^{*}$-belief goes no distance towards securing our cognitive goals. So the thing to do, cognitively speaking, is to $\mathrm{n}^{*}$-believe that one is not a victim of deception, for, whether or not one is a victim of deception, the cognitive state that is produced - be it a belief or a belief-in-anillusion - will be true.

\section{Skepticism at Another Level?}

I have argued that Cartesian skepticism can be defeated, because no matter whether or not we are victims of massive deception (or dreaming, or etc.), adopting the $\mathrm{n}^{*}$ belief that we are not so deceived will provide us with true cognitive attitudes. And since, from the first-person perspective, $n^{*}$-belief is indistinguishable from belief, the choice that the cognitive agent faces is about what to $\mathrm{n}^{*}$-believe. The skeptic's advice, to not $\mathrm{n}^{*}$-believe anything, is bad advice. It yields no cognitive payoff, whereas $\mathrm{n}^{*}$ believing that one is not deceived is guaranteed to yield a positive one.

One might be concerned that a response of this kind trades one kind of skepticism for another. The concern is that, though questions about the external world may have been answered to the extent possible, doubt is shifted from the external world to the internal one. For, since belief and belief-in-an-illusion are indistinguishable, the result of these reflections is that we do not have access to the nature of our representational states. Arguably, it is no gain to have our beliefs about the external world restored to us, if we can have no confidence that what has been restored to us are beliefs.

Though I feel the concern that motivates this objection acutely, I am not convinced that it holds merit. Consider the circumstances in which a cognitive agent finds herself. She must decide whether to $n^{*}$-believe that she has genuine beliefs, $\mathrm{n}$ *-believe that she has mere beliefs-in-an-illusion, or to suspend $\mathrm{n}$ *-belief on the question. If she is not a victim of deception, then $\mathrm{n}$ *-believing that she has genuine beliefs is genuinely believing that she has genuine beliefs. And this belief, of course,

Principia 17(2): 251-264 (2013). 
is true. If she has only recently become a victim of deception, then $\mathrm{n}$-believing that she has genuine beliefs yields the belief-in-an-illusion that she has genuine beliefs. And this belief-in-an-illusion is, indeed, true. Now, one's own beliefs are something that, unlike Winston Churchill, one cannot help but have causal commerce with. So if she has always been a victim of massive deception, then $\mathrm{n}$ *-believing that she has genuine beliefs yields the genuine belief that she has genuine beliefs. And this belief, too, is true. Conversely, $\mathrm{n}^{*}$-believing that she has mere beliefs-in-an-illusion will yield false cognitive attitudes. See Figure 4.

\begin{tabular}{|l|l|l|l|}
\hline & $\begin{array}{l}\mathbf{N}^{*} \text {-believe that you } \\
\text { have genuine beliefs }\end{array}$ & $\begin{array}{l}\mathbf{N}^{*} \text {-believe that you } \\
\text { have only beliefs- } \\
\text { in-an-illusion }\end{array}$ & $\begin{array}{l}\text { Suspend } \\
\mathbf{n}^{*} \text {-judgment } \\
\text { on the question }\end{array}$ \\
\hline $\begin{array}{l}\text { You are not a } \\
\text { victim of deception } \\
\text { (and so have } \\
\text { genuine beliefs) }\end{array}$ & $\begin{array}{l}\text { You get the true belief } \\
\text { that you have genuine } \\
\text { beliefs }\end{array}$ & $\begin{array}{l}\text { You get the false belief } \\
\text { that you have only } \\
\text { beliefs-in-an-illusion }\end{array}$ & No payoff \\
\hline $\begin{array}{l}\text { You have only } \\
\text { recently become a } \\
\text { victim of deception }\end{array}$ & $\begin{array}{l}\text { You get the true } \\
\text { belief-in-an-illusion } \\
\text { that you have } \\
\text { genuine beliefs }\end{array}$ & $\begin{array}{l}\text { You get the false } \\
\text { belief-in-an-illusion } \\
\text { that you have only } \\
\text { beliefs-in-an-illusion }\end{array}$ & No payoff \\
\hline $\begin{array}{l}\text { You have always } \\
\text { been a victim } \\
\text { of deception }\end{array}$ & $\begin{array}{l}\text { You get the true belief } \\
\text { that you have genuine } \\
\text { beliefs }\end{array}$ & $\begin{array}{l}\text { You get the false belief } \\
\text { that you have mere } \\
\text { beliefs-in-an-illusion }\end{array}$ & No payoff \\
\hline
\end{tabular}

Figure 4.

Since $\mathrm{n}$ *-believing that one has genuine beliefs always yields a true cognitive attitude, $\mathrm{n}$ *-believing that one has mere beliefs-in-an-illusion always yields a false one, and suspending $n *$-belief has no payoff, the thing to do, cognitively speaking, is to $n$ *-believe that one has genuine beliefs. Now one could, of course, wonder whether this state, that of $n^{*}$-believing that one has genuine beliefs, is itself a genuine belief or a mere belief-in-an-illusion. But the above argument can simply be run again. Ought one to $\mathrm{n}^{*}$-believe that it is a genuine belief? Yes; doing so yields a true cognitive attitude, whereas the best that any alternative course of action can offer is no cognitive attitude at all.

The skeptic's best hope was to show that one ought to suspend belief about the nature of one's cognitive states. And the skeptic can, of course, ask, of any given belief, whether it is a genuine belief or a mere belief-in-an-illusion. But any time that he asks this question we can reply with the argument given above. This will not prohibit the skeptic from asking the same question at one level higher, but it does show that all such questions can be answered. 


\section{Conclusion}

If Sosa and Malcolm are right about how representations in dreams (and other such states) work, and if Putnam is right about how reference works, a response to Cartesian skepticism is possible. $\mathrm{N}^{*}$-believing that one is not a victim of deception will yield a true cognitive attitude, no matter whether one is a victim of deception or not. No alternative course of action can say as much. Moreover, the Sosa/Malcolm and Putnam views together also allow us to show that, for any given $n^{*}$-belief that one may hold, one ought to $n^{*}$-believe that it is a genuine belief. We can, then, say that one ought to believe that one is not a victim of deception. And if we can, then the skeptic is defeated. ${ }^{7}$

\section{References}

BonJour, L. 1985. The Structure of Empirical Knowledge. Cambridge: Harvard University Press.

Davidson, D. 1991. Three Varieties of Knowledge. In: D. Davidson 1991. Subjective, Intersubjective, Objective. Oxford: Clarendon, p.205-20.

Grandy, R. 1973. Reference, Meaning, and Belief. The Journal of Philosophy 70: 439-52.

Klein, P. 1986. Radical Interpretation and Global Skepticism. In: E. Lepore (ed.) Truth and Interpretation: Perspectives on the Philosophy of Donald Davidson. Oxford: Blackwell, p.36986.

Malcolm, N. 1959. Dreaming. London: Routledge \& Kegan Paul.

Putnam, H. 1981. Reason, Truth and History. Cambridge: Cambridge University Press.

Sosa, E. 2007. A Virtue Epistemology: Apt Belief and Reflective Knowledge, Volume 1. Oxford: Clarendon.

Nicholas TebBen Department of Philosophy and Religious Studies

Towson University 8000 York Rd. Towson, Maryland 21252

USA

ntebben $1 @ j h u . e d u$

Resumo. A estratégia do Cético Cartesiano é contar uma história sobre o mundo que é inteiramente consistente com toda a evidência empírica que temos ou podemos ter, mas de acordo com a qual muitas de nossas crenças ordinárias são falsas. Ele então sugere que, como não podemos mostrar que sua história é falsa, devemos abandonar essas crenças. Neste artigo ofereço uma resposta baseada na teoria da decisão. Digamos que uma atitude cognitiva é uma atitude proposicional que pode ser verdadeira ou falsa. Eu argumento que rejeitar a história do cético e reter nossas opiniões ordinárias vai nos fornecer atitudes cognitivas verdadeiras, independentemente da história do cético ser verdadeira ou falsa, e que o melhor 
que qualquer alternativa pode fazer é não fornecer absolutamente nenhuma atitude cognitiva. Portanto, é racional reter nossas opiniões ordinárias. Alguns podem pensar que a razão para eu poder sustentar tal conclusão surpreendente é que as atitudes cognitivas em questão não são crenças reais, e não representam o mundo real. Eu termino o artigo argumentando que esta preocupação não se aplica ao caso.

Palavras-chave: Ceticismo; referência; sonhos; teoria da decisão.

\section{Notes}

${ }^{1}$ There are some responses that attempt this. See, for example, the concluding pages of BonJour 1985.

2 This would not be the first response to skepticism to provoke such a reaction. See, for example, Klein's response to Davidson at Klein 1986, p.383.

${ }^{3}$ The principle of charity is a methodological constraint on interpretation. One component of the principle of charity (see Davidson 1991, p.211) requires that one minimize the incoherence that one attributes to those whose speech and behavior one interprets. The other component requires that one attribute to one's subjects mostly true beliefs, though there is reason to doubt that this is sound methodological advice. (See Grandy 1973, p.443-5.)

${ }^{4}$ Sosa argues for this position throughout the first chapter of Sosa 2007.

${ }^{5}$ To make room for the possibility that there are "nested" dreams - dreams in which one dreams that one dreams - strictly speaking 'n-belief' will be neutral between real beliefs and beliefs-at-the-deepest-level-at-which-one-dreams. So if one dreams that one dreams that one is being chased by a lion, 'one's n-belief that one is being chased by a lion' will be neutral between referring to a real belief that one is being chased by a lion, and a belief-in-a-dreamin-a-dream that one is being chased by a lion. This complication will be ignored below.

${ }^{6}$ Not all radical skeptical hypotheses need to involve deception. But the earliest and most famous one - Descartes' supposition that he is deceived by an evil demon - does, and it is convenient for expository purposes to treat them all similarly, so I will allow massive deception to stand-in for radical skeptical hypotheses of all kinds. This should not effect the argument in any way.

${ }^{7}$ I would like to thank Michael Williams, Mike Hicks and Nick Goldberg for their comments on earlier drafts of this paper. Another draft was presented to the $8^{\text {th }}$ Principia International Symposium in Florianopolis, I would like to thank my audience at that event as well.

Principia 17(2): 251-264 (2013). 